\section{Hepatitt C tar liv hos tidligere og nåværende stoffbrukere}

Kronisk hepatitt C fører til leversvikt og leverkreft, som er viktige dødsårsaker hos pasienter smittet ved stoffinjeksjon. Tidlig diagnose og adekvat behandling er essensielt.

Kronisk hepatitt $\mathrm{C}$ utvikler seg ofte langsomt hos pasienter smittet $\mathrm{i}$ ung alder, men etter 25-35 år har $1 / 3$ av pasientene alvorlig leverfibrose eller levercirrhose. I min doktorgradsavhandling har jeg studert dødelighet og utvikling av leversykdom knyttet til kronisk hepatitt $\mathrm{C}$ hos mennesker smittet ved stoffinjeksjon. Omfanget av antiviral behandling mot hepatitt C-virus (HCV) ble også undersøkt.

En gruppe på 523 pasienter innlagt for rusbehandling 1970-84 ble fulgt i gjennomsnitt 33 år ved koblinger til helseregistre. Serum var lagret ved Folkehelseinstituttet og ble undersøkt for hepatitt-markører. Alle i denne gruppen hadde antistoff mot HCV. $63 \%$ hadde kronisk hepatitt $\mathrm{C}$, de øvrige var spontant blitt virusfrie. Leversykdom ble unders $ø$ kt ved mikroskopi av levervev fra obduksjoner.

Generell dødelighet var høy, hovedsakelig som følge av overdoser. Inntil omkring 50 års alder var dødeligheten den samme hos dem som hadde kronisk hepatitt C-virusinfeksjon og dem som var blitt virusfrie. Ved dødsfall ved alder over 50 år utgjorde leversykdom omkring $1 / 4$ av dødsfallene hos dem som hadde kronisk hepatitt C. Dermed ble dødeligheten i denne aldersgruppen høyere blant dem som hadde kronisk hepatitt C. I perioden 1997-2012 fikk 19\% av pasientene antiviral behandling mot infeksjonen. Dødeligheten hos de ubehandlede var mye høyere enn hos de behandlede, som følge av flere overdoser og dødsfall som skyldtes hepatitt $\mathrm{C}$ blant de ubehandlede.

Mange som bruker eller tidligere har brukt stoff med sprøyte er nå i ferd med å utvikle alvorlig leverfibrose eller cirrhose som følge av hepatitt C. Det er avgjørende at disse oppdages og får behandling tidsnok.

knkiella@online.no

\section{Knut Boe Kielland}

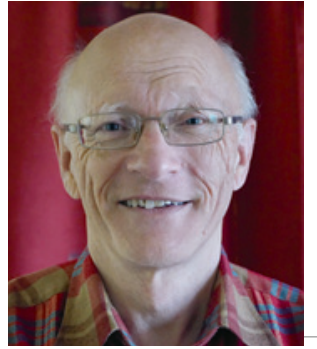

Knut Boe Kielland. Foto: Eva Røise

Disputas

Knut Boe Kielland disputerte for ph.d.-graden ved Universitetet i Oslo 3.11. 2015. Tittelen på avhandlingen er Mortality, morbidity and treatment uptake related to hepatitis $C$ among people who have injected drugs in Norway

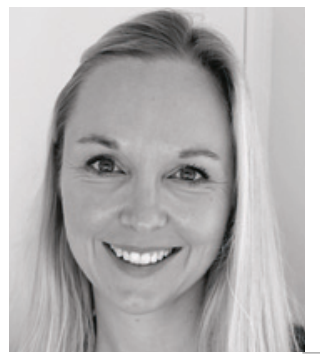

Lisa Aarhus. Foto: Mads Aarhus audiometrier i voksen alder. Mellomørebetennelse eller sensorinevralt hørselstap i barndommen var ikke forbundet med endret sårbarhet for senere støyrelatert hørselstap. Selv om støybeskyttelse fortsatt er viktig, er dette verdifull informasjon for personer som har et hørselstap fra barndommen av.

Studien har gitt økt kunnskap om langtidsprognosen ved øresykdom og hørselstap hos barn. Dette er viktig for å finne riktig nivå på forebyggende tiltak, behandling og oppfølging.

\section{Disputas}

Lisa Aarhus disputerte for ph.d.-graden ved Universitetet i Oslo 22.1. 2016. Tittelen på avhandlingen er Follow-up of childhood hearing disorders: hearing loss, tinnitus and dizziness in adulthood.
Sammenhengen mellom kronisk suppurativ mellomørebetennelse $\mathrm{i}$ barndommen og nedsatt hørsel, tinnitus og svimmelhet i voksen alder var tydelig. Sekretorisk mellomørebetennelse, både med og uten arr på trommehinnen, var assosiert med marginalt økte høreterskler senere i livet. Videre indi-

\section{Lisa Aarhus}

lisa.aarhus@stami.no 